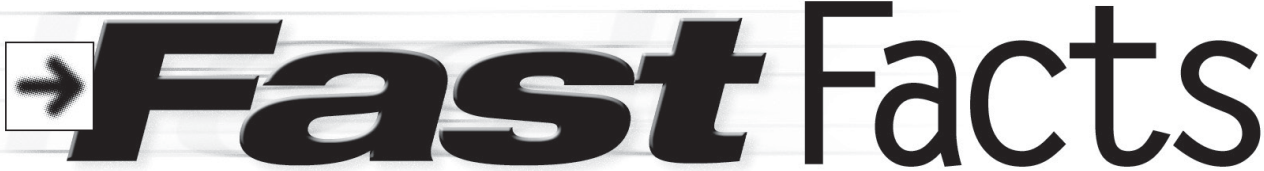

\begin{abstract}
$\rightarrow$ Digital divide
Digital technologies have spread rapidly in much of the world, but the broader development benefits from using these technologies have lagged behind. While more than 40 percent of the world's population has access to the Internet, nearly 6 billion people do not have high-speed Internet, making them unable to fully participate in the digital economy. Nearly 60 percent of the world's people are still offline. The less educated and the bottom 40 percent of the welfare distribution worldwide are most vulnerable to technological changes in the labor market. World Bank, "World Development Report 2016: Digital Dividends," Washington, D.C.: World Bank, doi:10.1596/978 -1-4648-0671-1, License: Creative Commons Attribution CC BY 3.0 IGO, www.worldbank.org/en/publication/wdr2016 (retrieved February 10, 2016).
\end{abstract}

\title{
$\rightarrow$ Research4Life
}

Research4Life is the collective name for the four programs-HINARI, AGORA, OARE, and ARDI - that provide developing countries with free or low-cost access to academic and professional peer-reviewed content online. The content comprises more than 45,000 peer-reviewed international scientific journals, books, and databases. Publicly funded not-for-profit institutions in most lowand-middle income countries are eligible to register for access to the content. Research4Life, "Research4Life fact sheet 2015," April 15, 2015, www.research4life.org/wp-content/uploads/2015/05 /R4L_factsheet_2015.pdf (retrieved January 6, 2016).

\section{Most educated cities}

"The most educated metropolitan area in the country is Washington, D.C., with San Jose being a close second." Measuring higher education degrees as a percentage of the $25+$ population, those two cities are followed by San Francisco, Boston, Raleigh, Austin, Denver, Minneapolis, Seattle, and New York to round out the top ten. As of 2014, "more women than men held a bachelor's degree or higher-30.2 percent to 29.9 percent."

Valerie Strauss, "Most Educated City in U.S.? Data Says It's Washington, D.C." The Washington Post, January 20, 2016, https://www.washingtonpost.com/news/answer-sheet/wp/2016/01/20/most-educated-city-in-u-s-data-says-its -washington-d-c (retrieved February 10, 2016).

\section{Institutional racism concerning higher education faculty}

"African Americans make up 13 percent of the U.S. population and 15 percent of the enrolled student population at America's colleges, but only 5.5 percent of all full-time faculty are black. Ninety-six percent of black tenured faculty are at (Historically Black Colleges and Universities) even though HBCUs comprise only 3 percent of the nation's 3,000 colleges and universities."

Warren Waren, "Institutional Racism: Comparing Oscar Nominations with Higher Education Faculty," RacismReview.com, January 26, 2016, www.racismreview.com/blog/2016/01/26/institutional-racism-comparing-oscar-nominations-higher -education-faculty (retrieved February 10, 2016).

\section{Print-only newspaper readers}

"Data from Pew Research Center and other sources show that around half of newspaper readers consume newspapers only in their printed form. They are more likely to often watch local TV news than those newspaper readers who access the paper online instead of or in addition to the print edition. This difference persists even when controlling for age."

Michael Barthel, "Around Half of Newspaper Readers Rely Only on Print Edition, " Pew Research Center, January 6, 2016, wmw.pewresearch.org/fact-tank/2016/01/06/around-half-of-newspaper-readers-rely-only-on-print-edition (retrieved February 10, 2016).

Gary Pattillo is reference librarian at the University of North Carolina-Chapel Hill, e-mail: pattillo@email. unc.edu 